\title{
MEASURING THE MEASURES: RULE OF LAW INDICES AND ABUSIVE LEGALISM
}

\author{
Alvin Y.H. Cheung
}

\section{INTRODUCTION}

Many things could be said of contemporary rule of law indicators. ${ }^{1}$ Indeed, it might seem that the one thing that could not be said is that there are too few of them. Nonetheless, existing rule of law indices all suffer from a host of methodological and conceptual problems, ranging from over-reliance on experts to an inability to articulate what the indices are actually measuring.

This article builds on previous critiques by addressing the potential for such indices to be "gamed." It does so by focusing on the hypothetical jurisdiction of Erewhon, and on the ways in which it might manipulate sub-constitutional legal norms and institutions in ways that consolidate the regime's position without attracting

\footnotetext{
* JSD Candidate, NYU School of Law. I am indebted to Professor Sam Issacharoff, Professor Kevin Davis, Professor Jeremy Waldron, Hugh Adsett, Alyssa S. King, and the participants at the NYU JSD Forum on 7 December 2018 for their comments on various versions of this chapter.

1 Tom Ginsburg, Pitfalls of Measuring the Rule of Law, 3 Hague J. Rule L. 269 (2011).
} 
unfavourable scrutiny, practices that I will refer to collectively as "abusive legalism."

I begin in Part I by outlining the current prevalence and role of rule of law indices, in order to illustrate why a government might wish to perform well in such indices. Part II addresses previous methodological and conceptual critiques of rule of law indices. I then consider what several leading rule of law indices measure in Part III, before introducing Erewhon in Part IV as a way to consider how a canny authoritarian might "game" rule of law indices, before critically evaluating existing rule of law indices in light of Erewhon in Parts V and VI. I offer some tentative conclusions and recommendations for addressing abusive legalist practices in Part VII.

\section{The Prevalence And Role of Rule-OF-LAw InDices}

As noted earlier, there is no shortage of indices that purport to measure the rule of law. In their 2017 survey of rule of law indicators, Mila Versteeg and Tom Ginsburg discuss four influential indices: the Worldwide Governance Indicators ("WGI"); the Heritage Foundation's Index of Economic Freedom ("Heritage"); Freedom House's Freedom in the World Index ("FW"); and the World Justice Project's Rule of Law 
Index ("WJP"). ${ }^{2}$ In an earlier review, Svend-Erik Skaaning considers a variety of other indices, including the Bertelsmann Transformation Index ("BTI") and Global Integrity's now-defunct Global Integrity Index ("GI"). ${ }^{3}$ All of these indices - with the sole exception of $\mathrm{FW}^{4}-$ began after the Cold War. ${ }^{5}$

I now turn to how rule of law indices matter in the international realm. I suggest here that, although there are instances of rule of law indices being used directly in making decisions on allocating development funds, the most significant role such indices have is in shaping the international discourse on the rule of law.

Some donors have tied rule of law reforms to other benefits, such as trade access or developmental aid. The Millennium Challenge Corporation ("MCC") in the US, for example, selects countries for foreign aid based on (inter alia) WGI "Rule of Law" performance. ${ }^{6}$ The

2 Mila Versteeg \& Tom Ginsburg, Measuring the Rule of Law: A Comparison of Indicators, 42 LAW \& SOC. INQUIRY 100, 101 (2017).

3 Svend-Erik Skaaning, Measuring the Rule of Law, 63 POL. RES. Q. 449, 450; The GI index ceased to be published after 2011: see Nathaniel Heller, Why We Killed the Global Integrity Index, Global Integrity, https://www.globalintegrity.org/2011/05/post-792/.

4 Christopher G. Bradley, International Organizations and the Production of Indicators: The Case of Freedom House, in THE QUIET POWER OF INDICATORS: MEASURING Governance, Corruption, And Rule of Law 34-35 (Sally Engle Merry et al. eds., 2015).

5 See, e.g., Previous Editions: WJP Rule of Law Index, World Justice Project, https://worldjusticeproject.org/our-work/wjp-rule-law-index/previous-editionswjp-rule-law-index (WJP first published 2008); Democracy under PressureâPolarization and Repression Are Increasing Worldwide, Bertelsmann Transformation Index, https://www.bti-project.org/en/about/connect/pressmedia-center/bti-2018-press-release/ (BTI first published 2006); Skaaning, supra note 4, at 450 (WGI and GI first published in 1996 and 2003 respectively).

6 Millennium Challenge Corporation, Millennium Challenge Corporation Fiscal Year 2019 Country Scorebook 3-4. The "Civil Liberties" indicator (citing FW) also refers explicitly to rule of law. Curiously, WJP does not feature at all. 
European Union has also purported to cultivate the rule of law abroad through, inter alia, the incorporation of rule of law provisions into cooperation and financial aid instruments. ${ }^{7}$ However, studies suggest that major donors have not consistently adopted conditionality ${ }^{8}$ (with the possible exception of the Copenhagen Criteria for EU accession, which include "stable institutions guaranteeing ... the rule of law"). ${ }^{9}$

However, the greater significance of rule of law indices appears to be in giving an apolitical and technocratic appearance to rule of law promotion. The World Bank has been a pioneer in such efforts, particularly under the tenure of then-General Counsel Ibrahim Shihata in the 1980s and 1990s. ${ }^{10}$ Shihata sought to distinguish "governance" from (impermissible) intervention in countries' internal political affairs; to that end, he seized on the rule of law as a banner that conveyed the appearance of political neutrality. ${ }^{11}$ A host of inter-governmental and

7 Isabelle Ioannides, Rule of Law in European Union External Action: Guiding Principles, Practices and Lessons Learned (International IDEA 2014) 14-22.

8 Frank Schimmelfennig, A Comparison of the Rule of Law Promotion Policies of Major Western Powers, in RULE OF LAW DYNAMICS IN AN ERA OF InTERnAtional AND TransNational GovernanCE 111, 124 (Michael Zurn et al. eds.).

9 Id.; Conditions for membershipâEuropean Neighbourhood Policy And Enlargement Negotiations, European Commission, https://ec.europa.eu/neighbourhoodenlargement/policy/conditions-membership_en; Daniel Smilov, EU Enlargement and the Constitutional Principle of Judicial Independence, in SPREADING DEMOCracy

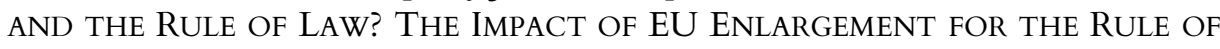

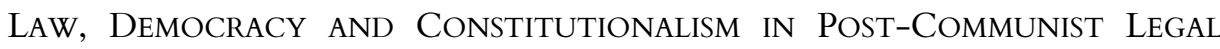
ORDERS 313, 320-26 (Wojciech Sadurski et al. eds., 2006).

10 Alvaro Santos, The World Bank's Uses of the "Rule of Law" Promise in Economic Development, in The New LaW and Economic Development: A CRitical Appraisal 253, 268 (David Trubek \& Alvaro Santos eds., 2006) (noting Shihata served in that rule between 1983 and 1998).

11 Id. at 269-73. 
non-governmental organisations, think tanks, and governments followed suit, giving the phrase a "talismanic" role. ${ }^{12}$

One consequence of this phenomenon is the invocation of the rule of law, and of purported measurements of the rule of law, as a way to claim and defend bureaucratic turf. The World Bank provides a particularly vivid illustration of the phenomenon. The World Bank as a whole came to adopt the rule of law as a way to justify expanding its remit. ${ }^{13}$ However, the rhetoric of rule of law also came to be used as a tool for infighting within the World Bank. Different units within the Bank have cited the WGI and Doing Business reports ${ }^{14}$ as ways of defending their respective projects, ${ }^{15}$ to such an extent that they have been accused of substituting the invocation of indicators for planning and evaluation. ${ }^{16}$

Another consequence is the use of rule of law rankings by governments to advertise a jurisdiction's openness to foreign investors. ${ }^{17}$ Firms choose their jurisdiction of incorporation, the location of their assets, and the governing law for dispute resolution strategically. ${ }^{18}$ In making these choices, they will have regard to the incentives a particular legal system offers. ${ }^{19}$ To that end, governments particularly reliant on transnational business, such as those in Singapore and Hong Kong, have 12 Stephen Humphreys, Theatre of the Rule of LAW 2 (2011).

13 Santos, supra note 11, at 273-75.

14 The latter do not purport to measure the rule of law as such, but they do measure the performance of certain legal norms and institutions.

15 Santos, supra note 11, at 292.

16 Id. at 292-95.

17 See generally Larry E. Ribstein \& Erin O'Hara, The Law Market 12-13, 224-25 (2009) (on the international "law market").

18 See id. at 66.

19 See id. at 73-77. 
touted their rule of law rankings as a way to signal attractiveness to investors. ${ }^{20}$

\section{Previous CRitiques of Rule of LAW InDices}

Prior studies of rule of law indices fall into two broad categories: (a) "deep" work that focuses on one particular index; and (b) "broad" work that surveys multiple indices, concluding with general critiques of each. However, these studies have generally not focused on ways in which such indices can be "gamed."

The criticisms that these studies level against rule of law indices fall into two broad categories: methodological, and theoretical. On a methodological level, some of the indices' criteria vary from year to year, ${ }^{21}$ and in at least one case (WGI) from country to country. ${ }^{22}$ Even

20 See, e.g., Opening speech by Minister for Law, K Shanmugam, at the In-House Counsel World Summit 2014 । Ministry of Law, http://www.mlaw.gov.sg/content/minlaw/en/news/speeches/opening-speech-byminister-for-law-at-in-house-counsel-world-summit-2014.html (Singapore, citing WJP); Speech by Minister for Law and Minister for Foreign Affairs, K Shanmugam, at at the International Bar Association 4th Asia Pacific Regional Forum Conference | Ministry of Law, http://www.mlaw.gov.sg/content/minlaw/en/news/speeches/speech-by-ministershanmugam-IBA-4th-AP-regional-forum-conference.html (Singapore, citing WJP); Rimsky Yuen, Speech by the Secretary for Justice at the Ceremonial Opening of the Legal Year 2016 (2016) (HK, citing WGI); Teresa Cheng, Speech by the Secretary for Justice at the Ceremonial Opening of the Legal Year 2018 (2018) (HK, citing WGI).

21 See, e.g., Jørgen Møller \& Svend-Erik SkaAning, The Rule of Law: Definitions, Measures, Patterns And Causes 54 (2014) (WGI and FH); Rule of Law Index 2019 (World Justice Project), Feb. 2019; Rule of Law Index 2016 (World Justice Project); Mark David Agrast et al., The Rule of Law Index (World Justice Project 2008) (illustrative examples of changes in WJP over time).

22 Møller \& SKaAning, supra note 22, at 54; Wolfgang Merkel, Measuring the Quality of Rule of Law, in RULE OF LAW DYNAMICS IN AN ERA OF INTERNATIONAL AND TRANSNATIONAL GOVERNANCE 21, 27-28 (2012). 
where criteria are relatively consistent, indices typically rely heavily on expert coding, ${ }^{23}$ and are subject to informational constraints. ${ }^{24}$ Such constraints may take several forms. Some of the experts involved may not be resident in the society they are assessing. ${ }^{25}$ The information available to experts may be significantly affected by the media reporting available to them. ${ }^{26}$ Experts may also (explicitly or otherwise) take account of information produced by other rule of law indicators, or may rely on scores given by the same indicator in previous years. ${ }^{27}$ Nonetheless, the extent to which such methodological limitations affect rule of law indices remains unclear. ${ }^{28}$

In addition, previous work on rule of law indices includes extensive criticism of the theoretical deficiencies of such indices. Thomas' critique of the WGI attacks the indicators' "construct validity" - pointing out that (inter alia) the rule of law indicator in WGI does not match up with any major theoretical definition of the rule of law. ${ }^{29}$ Svend-Erik Skaaning and Jørgen Møller, ${ }^{30}$ and Mila Versteeg and Tom

23 MØLlER \& SKAANING, supra note 22, at 55; Versteeg \& Ginsburg, supra note 3, at 119.

24 Versteeg \& Ginsburg, supra note 3, at 119.

25 See also Rule of Law Index 2019, supra note 22, at 163 (noting "the limited number of experts in some countries").

26 See Kevin E. Davis, What Can The Rule of Law Variable Tell Us About Rule of Law Reforms?, 26 MiCH. J. INT'L L. 141, 150 (2004) (addressing the International Country Risk Guide's rule-of-law measurements).

27 Versteeg \& Ginsburg, supra note 3, at 119.

28 See id. at 124.

29 M.A. Thomas, What Do the Worldwide Governance Indicators Measure?, 22 EUR. J. Dev. Res. 31, 39-41 (2010).

30 Skaaning, supra note 4, at 451-53; MøLLER \& SKAANING, supra note 22, at 45-53. 
Ginsburg, ${ }^{31}$ have made similar criticisms of the "definitions" of the rule of law present in other indices.

Much of this work endorses a relatively "thin," formal account of the rule of law, ${ }^{32}$ typically for two reasons. First, it would confine the rule of law to less contested elements, ${ }^{33}$ reducing the scope for a direct challenge to such indices on (for instance) ideological grounds. Second, it would result in less overlap between legal and non-legal factors, ${ }^{34}$ and less overlap with neighbouring concepts such as human rights and democracy. ${ }^{35}$ This in turn would reduce the scope for double-counting. However, these studies do not go on to suggest how such conceptual deficiencies might give rise to strategies to abuse the indices.

\section{WHAT DO THE INDICES MEASURE?}

\section{Before considering how a canny authoritarian might "game"}

these indices, it falls to consider the substance of such indices in greater

31 Versteeg \& Ginsburg, supra note 3, at 103-9.

32 Skaaning, supra note 4, at 451; MølleR \& SKAANING, supra note 22, at 45-46; Versteeg \& Ginsburg, supra note 3, at 105-6; Ronald Janse et al., Rule of Law Inventory Report: Academic Part (Hague Institute for the Internationalisation of Law 2007) ๆ 8.

33 See, e.g., Versteeg \& Ginsburg, supra note 3, at 105; Møller \& SKAANING, supra note 22 , at $45-46$.

34 See, e.g., Davis, supra note 27, at 149-50 (explaining how crime rates simpliciter are not an adequate proxy for information about a society's legal system). Manipulation of extra-legal factors such as informal social networks, the state of the economy, and the like may offer scope for "gaming" rule of law measurements.

35 Versteeg \& Ginsburg, supra note 3, at 105-6; MøLlER \& SKAANING, supra note 22, at 46; Stefan Voigt, How to Measure the Rule of Law, MAGKS Papers on Economics 200938 (Philipps-Universität Marburg, Faculty of Business Administration and Economics, Department of Economics (Volkswirtschaftliche Abteilung) 2009) 7-8 (arguing that law and order, citizens' respect for formal legislation, democracy, market economy, and human rights should be kept distinct from rule of law). 
detail. In this part, I set out the substantive criteria of some of the leading rule of law indices. For reasons I discuss at the end of this part, I contend that the "threat models" that the major indices adopt leave broad openings for abusive practices. ${ }^{36}$

\section{The Worldwide Governance Indicators (WGI)}

The WGI treats rule of law as one of six inter-related "dimensions of governance." ${ }^{37}$ Despite the importance WGI purports to attach to rule of law, remarkably little attention is devoted to explaining what it is. In their paper outlining the WGI methodology, Kaufmann, Kraay, and Mastruzzi devote only one sentence to explaining the rule of law:

"perceptions of the extent to which agents have confidence in and abide by the rules of society, and in particular the quality of contract enforcement, property rights, the police, and the courts, as well as the likelihood of crime and violence." ${ }^{38}$

This appears to translate into four main limbs: (1) contract enforcement; (2) property rights; (3) the role and independence of the court system; and (4) questions of basic law and order such as the

36 With the exception of WGI, which offers so little by way of definition or explanation that it is difficult to identify a "threat model" at all.

37 Daniel Kaufmann et al., The Worldwide Governance Indicators: Methodology and Analytical Issues, 3 Hague J. Rule L. 220, 223-24 (2011).

38 Id. at 223. 
prevalence of violent or organised crime. ${ }^{39}$ In contrast, WGI gives much less attention to the subjection of public power to law, or to arbitrary conduct by the executive. ${ }^{40}$ In Figure 1 below I list the factors that WGI considers in the order in which WGI lists them, ${ }^{41}$ along with their sources. I also categorise the factor either as one of the four categories in the WGI definition, or as "Other." Where one factor arguably falls into two or more categories, I have identified it as such. It will be evident from Figure 1 that WGI is predominantly concerned with law and order, property rights, and judicial independence.

\footnotetext{
$\begin{array}{llll}39 \text { Rule } & \text { Law, } & \text { WGI } & \\ & \end{array}$ http://info.worldbank.org/governance/wgi/rl.pdf.

$40 \mathrm{Id}$.

41 With the exception of the now-defunct Global Integrity index.
} 
Figure 1. Factors and sources considered by WGI (except Global Integrity index), categorised ${ }^{42}$

\section{Source}

Economist Intelligence Unit

World Economic Forum

Competitiveness Report

Gallup World Poll

\section{Heritage}

Institutional Profiles Database

42 Based on Rule of Law, supra note 40.

\section{Factor}

Violent crime

Organised crime

Fairness of judicial process

Enforceability of contracts

Speediness of judicial process

Confiscation/expropriation

Intellectual property rights protection

Private property protection

GlobalBusiness cost of crime and violence

Cost of organised crime

Reliability of police services

Judicial independence

Efficiency of legal framework

challenging regulations

IPR protection

Property rights

Informal sector

Confidence in the police force

Confidence in judicial system

Have you had money property stolen fromLaw and order you or another household member?

Have you been assaulted or mugged?

Property rights

Degree of security of goods and persons

Violent activities by criminal organisations
Law and order

Category

Law and order

Judicial role and independence

Contract enforcement

Judicial role and independence

Property rights

Property rights

Property rights

Law and order

Law and order

Law and order

Judicial role and independence

forJudicial role and independence

Property rights

Property rights

Other

Law and order

Judicial role and independence

Law and order

Property rights

Property rights; law and order

Law and order 
Source

\section{Factor}

Category

Degree of judicial independence vis-a-visJudicial role and independence the State

Degree of enforcement of court orders Judicial role and independence Timeliness of judicial decisions Judicial role and independence

Equal treatment of foreigners before the lawOther

(compared to nationals)

Practical ability of the administration toOther

limit tax evasion

Efficiency of the legal means to protectProperty rights

property rights in the event of conflict

between private stakeholders

Generally speaking, does the State exerciseProperty rights

arbitrary pressure on private property?

Does the State pay compensation equal toProperty rights

the loss in cases of expropration (by law or

fact) when the expropriation concerns land

ownership?

Does the State pay compensation equal toProperty rights

the loss in cases of expropration (by law or

fact) when the expropriation concerns

production means?

Degree of observance of contractual termsContract enforcement between national private stakeholders

Degree of observance of contractual termsContract enforcement between national and foreign private

stakeholders

In the past 3 years, has the State withdrawnContract enforcement 
Source

Political Risk Services

US State Dept Trafficking in People Report Trafficking in people

Varieties of Democracy Project

Global Insight Business Conditions and RiskExpropriation

Indicators

State contract alteration

Contract enforcement

national stakeholders?

foreign stakeholders?

patents

\section{Factor}

from contracts without paying the

corresponding compensation... vis-à-vis

In the past 3 years, has the State withdrawn Contract enforcement

from contracts without paying the

corresponding compensation... vis-à-vis

Respect for intellectual property rightsProperty rights

relating to... trade secrets and industrial

Respect for intellectual property rightsProperty rights relating to... industrial counterfeiting

Does the State recognize formally theProperty rights diversity of land tenure system?

Law and order Law and order

Liberal component index (rule of law;Judicial role and independence; law and judicial independence; checks andorder; property rights; other

African Development Bank Country PolicyProperty rights and rule based governanceProperty rights; contract enforcement; law and Institutional Assessments

(property rights; contract rights; and order; other
predictability of laws and regulations;
judicial independence; access to justice;

judicial independence; access to justice;

43 V-Dem Institute, Varieties of Democracy Codebook V9 Apr. 2019 ฯा 2.2.8-2.2.11. 


\section{Source}

Afrobarometer

\section{Factor}

protection of citizens' lives and property)

Over the past year, how often have you orLaw and order anyone in your family feared crime in your

own home?

Over the past year, how often have you orLaw and order; property rights anyone in your family had something stolen

from your house?

Over the past year, how often have you orLaw and order anyone in your family been physically attacked?

How much do you trust the courts of law? Judicial role and independence Trust police

\section{Category}

Asian Development Bank Country PolicyProperty rights and rule based governanceProperty rights; contract enforcement; law and Institutional Assessments (property rights; contract rights; and order; other predictability of laws and regulations; judicial independence; access to justice; protection of citizens' lives and property)

Business Enterprise Environment Survey

How often is following characteristicjudicial role and independence associated with the court system: Fair and

honest?

How often is following characteristicJudicial role and independence associated with the court system:

Enforceable?

How often is following characteristicJudicial role and independence associated with the court system: Quick?

How problematic is crime for the growth ofLaw and order your business? 


\section{Source}

Bertelsmann Transformation Index

Freedom House

Judicial accountability

How problematic is judiciary for the growthJudicial role and independence of your business?

Rule of law (Separation of powers; judicialJudicial role and independence; other independence; prosecution of office abuse;

civil rights)

Judicial accounta

Access to water for agriculture

Latinobarometro

Trust in judiciary

Trust in police

Have you ever been a victim of crime? Law and order

World Bank Country Policy andProperty rights and rule based governanceProperty rights; contract enforcement; law

Institutional Assessments

(property rights; contract rights; and order; other

predictability of laws and regulations;

judicial independence; access to justice;

protection of citizens' lives and property) ${ }^{44}$

Vanderbilt University Americas Barometer Trust in supreme court

Trust in justice system

Trust in police

Judicial role and independence

Judicial role and independence; other

Have you been a victim of crime?

Law and order

Institute for Management and DevelopmentTax evasion is not a threat to your economy Other

World Competitiveness Yearbook

Justice is fairly administered

Judicial role and independence

Personal security and private property rightsProperty rights; law and order are adequately protected

Parallel (black-market, unrecorded)Other

economy does not impair economic

44 World Bank, CPIA Criteria 2017 (2017) 33-35. 
Source

World Justice Project

\section{Factor}

development

Intellectual property rights are adequatelyProperty rights enforced

Crime effectively controlled

Civil justice

Criminal justice

\section{Category}

Law and order

Judicial role and independence; contract enforcement; property rights

Judicial role and independence; law and order 


\section{Heritage}

The Heritage index specifically addresses three factors under the heading of "rule of law": property rights, judicial effectiveness, and government integrity. These topics appear to have been chosen as a result of ideology, rather than legal theory. ${ }^{45}$ Heritage does not explain how components or sub-components are coded or weighted. ${ }^{46}$ Nor does it offer further disaggregated data that shows e.g. how the property rights score was arrived at, ${ }^{47}$ or what specific sources were used for specific sub-components. Figure 2 below shows the sub-components in Heritage, organised by category:

45 See Versteeg \& Ginsburg, supra note 3, at 106-7.

46 Terry Miller et al., Index of Economic Freedom 2018 (Heritage Foundation), Jan. 2018 453-55.

47 Economic Data and Statistics on World Economy and Economic Freedom, Heritage Foundation, https://www.heritage.org/index/explore. 
Figure 2. Heritage Index

Category

Property rights

Judicial effectiveness

Government integrity

\section{Factor}

Physical property rights

Intellectual property rights

Strength of investor protection

Risk of expropriation

Quality of land administration

Judicial independence

Quality of judicial process

Likelihood of obtaining favourable judicialWorld Bank Doing Business Reports decisions

Public trust in politicians

Irregular payments and bribes

Transparency of government policymaking WJP

Absence of corruption

Perceptions of corruption

Perceptions Index

Competitiveness Report

World Bank Doing Business Reports

Credendo Group Country Risk Assessment

World Economic Forum World

Competitiveness Report

Governmental and civil service transparency TRACE International Trace Matrix 
Save for a brief reference to government enforcing property law effectively, Heritage is unconcerned with the prospect that vast areas of law might be uncertain or unevenly enforced. ${ }^{48}$ Although the index refers to "judicial effectiveness" as a key plank of the rule of law, it does not consider whether executive conduct is meaningfully constrained by law (except insofar as it relates to private property rights). ${ }^{49}$ Although Heritage does refer to "government integrity," its account of that factor appears to presuppose that corruption is the main threat to transparent and trustworthy executive conduct. ${ }^{50}$

\section{Freedom in the World (FW)}

FW has an explicit focus on political rights (which FW largely treats as related to representation and participation in government) and civil liberties (largely relating to substantive rights). FW treats the rule of law as a subset of the latter. ${ }^{51}$ Figure 3 shows the categories within FW's rule of law component, along with their constituent factors:

48 Miller et al., supra note 47 , at 453-54.

49 Id. at 454.

50 Id. at 454-55. Heritage does not offer any further explanation of "Governmental and civil service transparency."

51 Methodology 2019, Freedom House (Jan. 15, 2019), https://freedomhouse.org/report/methodology-freedom-world-2019. 


\section{Figure 3. Categories within FW's rule of law component ${ }^{52}$}

\section{Category}

F1. Is there an independent judiciary?

F2. Does due process prevail in civil and criminal matters?

52 See id. sec. F.

\section{Factors}

Is the judiciary subject to interference from the executive branch of government or from other political, economic, or religious influences?

Are judges appointed and dismissed in a fair and unbiased manner? Do judges rule fairly and impartially, or do they commonly render verdicts that favor the government or particular interests, whether in return for bribes or for other reasons?

Do executive, legislative, and other governmental authorities comply with judicial decisions, and are these decisions effectively enforced?

Do powerful private entities comply with judicial decisions, and are decisions that run counter to the interests of powerful actors effectively enforced?

Are defendants' rights, including the presumption of innocence until proven guilty, protected?

Do detainees have access to independent, competent legal counsel regardless of their financial means?

Are defendants given a fair, public, and timely hearing by a competent, independent, and impartial tribunal?

Is access to the court system in general dependent on an individual's financial means?

Are prosecutors independent of political control and influence?

Are prosecutors independent of powerful private interests, whether legal or illegal?

Do law enforcement and other security officials operate 


\section{Category}

F3. Is there protection from the illegitimate use of physical forceDo law enforcement officials beat detainees during arrest or use and freedom from war and insurgencies?

F4. Do laws, policies, and practices guarantee equal treatment ofAre members of various distinct groups-including ethnic, various segments of the population?

\section{Factors}

professionally, independently, and accountably?

Do law enforcement officials make arbitrary arrests and detentions without warrants, or fabricate or plant evidence on suspects?

Do law enforcement and other security officials fail to uphold due process because of influence by nonstate actors, including organized crime, powerful commercial interests, or other groups? excessive force or torture to extract confessions?

Are conditions in pretrial detention facilities and prisons humane and respectful of the human dignity of inmates?

Do citizens have the means of effective petition and redress when they suffer physical abuse by state authorities?

Is violent crime common, either in particular areas or among the general population?

Is the population subjected to physical harm, forced removal, or other acts of violence or terror due to civil conflict or war? effectively exercise their human rights with full equality before the law?

Is violence against such groups considered a crime, is it widespread, and are perpetrators brought to justice?

Do members of such groups face legal and/or de facto discrimination in areas including employment, education, and housing because of their identification with a particular group?

Do noncitizens-including migrant workers and noncitizen immigrants-enjoy basic internationally recognized human rights, 
Category

\section{Factors}

including the right not to be subjected to torture or other forms of ill-treatment, the right to due process of law, and the freedoms of association, expression, and religion?

Do the country's laws provide for the granting of asylum or refugee status in accordance with the 1951 UN Convention Relating to the Status of Refugees, its 1967 Protocol, and other regional treaties regarding refugees? Has the government established a system for providing protection to refugees, including against refoulement (the return of persons to a country where there is reason to believe they would face persecution)? 
As with the other indices discussed thus far, most of the factors considered by FW relate to (a) the role and independence of the judiciary $;^{53}$ (b) corruption, $;^{54}$ and (c) basic law and order. ${ }^{55}$ Executive compliance with law, or the arbitrary exercise of executive discretion, are addressed only sporadically - if at all. ${ }^{56}$ Similarly, unequal treatment is addressed only with respect to identified "distinct groups," and is framed in the language of human rights. ${ }^{57}$

\section{The Bertelsmann Transformation Index (BTI)}

The BTI subdivides the rule of law into four broad categories: separation of powers, judicial independence, prosecution of office abuse, and de jure and de facto protection of civil rights. ${ }^{58}$ However, these categories appear to be overly broad and in some cases overlapping. For instance, the separation of powers is described as including "the subjection of state power to the law;";9 a description that overlaps both with judicial independence ${ }^{60}$ and with the prosecution of officeholders for (inter alia) unlawful acts. ${ }^{61}$ The BTI is also not necessarily directly

\footnotetext{
53 See Methodology 2019, supra note 52 (F1 and parts of F2).

54 See id. (parts of F1 and F2).

55 See id. (F3).

56 See id. (specifically addressing only compliance with judicial decisions in F1, and the conduct of law enforcement and prosecutors in F2).

57 See id. (F4).

58 BTI 2018 Codebook for Country Assessments (Bertelsmann Stiftung 2018) 20-21.

$59 I d$. at 20.

60 Id.; MøLLER \& SKAANING, supra note 22, at 53.

61 BTI 2018 Codebook for Country Assessments, supra note 59, at 21.
} 
comparable to the other indicators considered here, as it is explicitly confined to developing and transforming countries. ${ }^{62}$

\section{The World Justice Project (WJP)}

The WJP starts with an expansive definition of the rule of law, originally articulated by William H Neukom, formerly General Counsel of Microsoft: ${ }^{63}$

"a rules-based system in which the following four universal principles are upheld: (1) the government and its officials and agents are accountable under the law; (2) the laws are clear, publicized, stable, and fair, and protect fundamental rights, including the security of persons and property; (3) the process by which the laws are enacted, administered, and enforced is accessible, fair, and efficient; and (4) access to justice is provided by competent, independent, and ethical adjudicators, attorneys or representatives, and judicial officers who are of sufficient number, have adequate resources, and reflect the makeup of the communities they serve." ${ }^{64}$

The WJP relies on eight factors in its index, all purportedly drawn from Neukom's definition: (1) limited government powers; (2)

62 Methodology, Bertelsmann Transformation Index, https://www.bti-project.org/en/index/methodology/.

63 Juan C. Botero \& Alejandro Ponce, Measuring the Rule of Law, World Justice Project Working Paper Series 1 (World Justice Project), Nov. 20105 (footnote 2). 64 Id. 
absence of corruption; (3) order and security; (4) fundamental rights; (5) open government; (6) effective regulatory enforcement; (7) access to civil justice; and (8) effective criminal justice. ${ }^{65}$ In practice, most of the sub-factors concern democratic government, ${ }^{66}$ substantive civil and political rights, ${ }^{67}$ law and order, ${ }^{68}$ corruption, ${ }^{69}$ and judicial independence and impartiality. ${ }^{70}$ I reproduce these factors and subfactors in Figure 4 below:

65 Id. at 8 .

66 Rule of Law Index 2019, supra note 22, at 11 (factor 1, especially subfactors 1.1, 1.5, and 1.6; subfactor 3.3).

67 Id. at 10-13 (including subfactor 1.5 and factor 4).

$68 I d$. at 12 (subfactor 4.2, factor 5).

69 Id. at 11, 13 (subfactors $2.1-2.4,6.2,7.3,8.1$, and 8.5).

70 Id. (factors 1.2, 2.2, 7.3 7.4, 8.4, and 8.6). 


\section{Figure 4. Factors and sub-factors in $\mathrm{WJP}^{71}$}

\section{Factor}

1. Constraints on government powers

2. Absence of corruption

3. Open government

4. Fundamental rights

71 Taken from $i d$. at 10

\section{Sub-factor}

1.1 Government powers are effectively limited by the legislature

1.2 Government powers are effectively limited by the judiciary

1.3 Government powers are effectively limited by independent auditing and review

1.4 Government officials are sanctioned for misconduct

1.5 Government powers are subject to non-governmental checks

1.6 Transition of power is subject to the law

2.1 Government officials in the executive branch do not use public office for private gain

2.2 Government officials in the judicial branch do not use public office for private gain

2.3 Government officials in the police and military do not use public office for private gain

2.4 Government officials in the legislative branch do not use public office for private gain

3.1 Publicised laws and government data

3.2 Right to information

3.3 Civic participation

3.4 Complaint mechanisms

4.1 Equal treatment and absence of discrimination

4.2 The right to life and security of the person is effectively guaranteed

4.3 Due process of the law and rights of the accused

4.4 Freedom of opinion and expression is effectively guaranteed

4.5 Freedom of belief and religion is effectively guaranteed 


\section{Factor}

5. Order and security

6. Regulatory enforcement

7. Civil justice

8. Criminal justice

\section{Sub-factor}

4.6 Freedom from arbitrary interference with privacy is effectively guaranteed

4.7 Freedom of assembly and association is effectively guaranteed

4.8 Fundamental labour rights are effectively guaranteed

5.1 Crime is effectively controlled

5.2 Civil conflict is effectively limited

5.3 People do not resort to violence to redress personal grievances

6.1 Government regulations are effectively enforced

6.2 Government regulations are applied and enforced without improper influence

6.3 Administrative proceedings are conducted without unreasonable delay

6.4 Due process is respected in administrative proceedings

6.5 The government does not expropriate without lawful process and adequate compensation

7.1 People can access and afford civil justice

7.2 Civil justice is free of discrimination

7.3 Civil justice is free of corruption

7.4 Civil justice is free of improper government influence

7.5 Civil justice is not subject to unreasonable delay

7.6 Civil justice is effectively enforced

7.7 Alternative dispute resolution mechanisms are accessible, impartial, and effective

8.1 Criminal investigation system is effective

8.2 Criminal adjudication system is timely and effective

8.3 Correctional system is effective in reducing criminal behaviour 
Sub-factor

8.4 Criminal justice system is impartial

8.5 Criminal justice system is free of corruption

8.6 Criminal justice system is free of improper government influence

8.7 Due process of the law and rights of the accused 


\section{Common Assumptions}

It should now be apparent that there are certain common threads that run through the substantive criteria of the major rule of law indices.

The first of these is an emphasis on law and order. WGI, FW, and WJP all address consider the presence or absence of armed conflict, violent crime, and organised crime as part of their indices.

The second thread is a focus on private property. Heritage ${ }^{72}$ and $\mathrm{WGI}^{73}$ in particular devote considerable attention to property rights and compensation for expropriation. $\mathrm{WJP}^{74}$ also includes property protection among the factors it considers, but gives it less prominence than Heritage or WGI.

The third commonality is the attention given to the role and independence of the courts and judiciary. All of the indices address, at length, the independence and impartiality of judges; ${ }^{75}$ some also consider the degree to which court orders are enforced. ${ }^{76}$

Fourth, the indices treat corruption as the primary threat to both judicial independence and sound administration. In considering whether judges are independent, or whether public officeholders have abused their positions, the underlying assumption appears to be that the

72 Miller et al., supra note 47 , at $453-54$.

73 Rule of Law, supra note 40.

74 Rule of Law Index 2019, supra note 22, at 12-13 (factor 5; subfactor 6.5).

75 See, e.g., Rule of Law, supra note 40 (references to judicial independence and confidence in the judicial system); BTI 2018 Codebook for Country Assessments, supra note 59, at 20 (factor 3.2 on judicial independence); Miller et al., supra note 47, at 454 ("judicial effectiveness"); Rule of Law Index 2019, supra note 22 (factors 1.2, 2.2, 7, 8.2, 8.4, 8.5, 8.6, and 8.7); Methodology 2019, supra note 52 (factor F1).

76 See, e.g., Methodology 2019, supra note 52 (factor F1); Rule of Law, supra note 40 ("Degree of enforcement of court orders"); Rule of Law Index 2019, supra note 22 (factor 1.2). 
most common abuse of office or lack of judicial independence is bribery. ${ }^{77}$

Fifth, all of the indices implicitly adopt "thick" notions of the rule of $\mathrm{law}^{78}$ - all of them contain some reference to substantive rights, and some draw a link between the rule of law and democratic government.

\section{INTRODUCING EREWHON}

Having set out the common themes of the major rule of law indices, it is now possible to consider how such indices might be "gamed," using the hypothetical jurisdiction of Erewhon. I intend to make two arguments. First, the assumptions and "threat models" underpinning the major indices ${ }^{79}$ do not hold true in an Erewhon scenario. Second, the major indices do not give sufficient emphasis to outliers or worst-case scenarios.

Suppose that Erewhon is a country with the following characteristics:

77 See BTI 2018 Codebook for Country Assessments, supra note 59 (factor 3.3, specifically referring to "corrupt practices" and "political corruption"); Rule of Law Index 2019, supra note 22 (factors 2, 6.2, 7.3, 8.5); Miller et al., supra note 47, at 454-55 (discussion of "government integrity"); Methodology 2019, supra note 52 (factor F1 referring to judges favouring particular interest "whether in return for bribes or for other reasons").

78 See, e.g., MøLLER \& SKAANING, supra note 22, at 46 (considering seven indices, including BTI, WGI, FH, and WJP).

79 With the exception of WGI, which offers so little by way of definition or explanation that it is difficult to identify a "threat model" at all. 
- It boasts a written constitution and legislation that have been carefully modelled on those in leading commercial jurisdictions; $;$

- All primary legislation has been scrupulously enacted and publicised, in accordance with normal legislative procedure;

- Erewhon's bureaucracy is staffed by efficient, well-paid civil servants who are not corruptible by private parties;

- Erewhon does not suffer from civil conflict. Suppose further that Erewhonese law enforcement is highly respected and that violent crime and organised crime are rare;

- Erewhon's economy is highly reliant on foreign investment and/ or development aid. Further suppose that investors and donors are attracted to Erewhon because its legal environment resembles that of their home jurisdiction.

Now suppose that the president of Erewhon intends to consolidate her political control. To that end, she intends to use all legal methods at her disposal to stamp out political opponents. However, the president knows her country's economy needs to retain the confidence of foreign investors and donors, by keeping a reassuringly familiar legal environment. She knows that any overt erosion of rights (for instance through national security legislation), or an obvious attempt to undermine the courts' independence, will trigger capital flight. What can she do?

80 For these purposes, nothing turns on whether Erewhon is common-law or civillaw. 
These constraints do not mean that the president's hands are tied. ${ }^{81}$ She might suggest particular enforcement priorities to her Department of Justice - priorities that just so happen to put her political opponents in the firing line. She might issue administrative guidelines to her bureaucrats, directing them to exercise their discretion in ways that systematically disfavour political undesirables - by targeting their views (directly or indirectly), or by imposing so many conditions on their operations that compliance becomes impossible. She might even farm out some of the dirty work to "private" actors, by getting sympathetic or proxy individuals or corporations to bring private law actions against political opponents. All of these moves can put political opponents at a significant disadvantage well before the matter ever reaches a judge, by forcing them to expend time, money, and effort. It scarcely matters how independent the court is, if the defendant has already "lost" by the time he gets there.

At this point one might ask: what exactly is wrong with these tactics? How - if at all - are they inconsistent with the rule of law? One response would be to say that they violate certain fundamental rights - freedom of expression, freedom of association, and so on. However, there are two objections to such an approach. The first is to reject the role of human rights altogether, or to argue that human rights in general are overridden by other social factors (e.g. the "Asian Values" argument). ${ }^{82}$ The second is to acknowledge that the tactics in question

81 See also Juan Carlos Botero et al., Indices and Indicators of Justice, Governance, and the Rule of Law: An Overview, 3 Hague J. Rule L. 153, 159-60 (2011) (addressing the possibility of "gaming" rule of law indicators).

82 See, e.g., Versteeg \& Ginsburg, supra note 3, at 105. 
inhibit certain specific rights, but to argue that these restrictions are somehow justified (for instance, by reference to public order).

Another response would be to say that, quite apart from any infringement of substantive rights, these tactics are inconsistent with even a relatively "thin" conception of formal legality. Møller and Skaaning identify several core principles that are common to the "thin" conceptions advanced by Fuller, Raz, and Finnis: ${ }^{83}$

(1) That laws be general ("generality");

(2) That laws be promulgated ("promulgation");

(3) That laws be prospective and not retroactive ("prospectivity");

(4) That laws be clear ("clarity");

(5) That laws be consistent with one another ("internal consistency");

(6) That laws be relatively stable ("stability");

(7) That laws be possible to comply with ("possibility for compliance"); and

(8) That there be congruence between official actions and declared rules ("congruence").

Møller and Skaaning also refer to two "expansions" to these principles, namely (9) that members of the general public comply with the law; and (10) equality under the law and before the courts. ${ }^{84}$ Taken together, these principles cover the common meanings of the phrase 83 See MøLler \& SKAANING, supra note 22, at 15 (Table 1.1). 84 See id. at 14-16. 
"rule of law," with the exception of accounts that refer to substantive rights or popular democratic consent. ${ }^{85}$

It should now be apparent how one can criticise Erewhon based on formal legality. The uneven or selective application of laws infringes the principles of congruence and of equality under the law. The capricious exercise of discretion violates the principle of congruence. The adoption of secret "administrative guidelines" is inconsistent with at a minimum - the principle of promulgation. Making rules practically impossible to comply with is a self-evident violation of formal legality. Farming out executive conduct to "private" actors is harder to reconcile with the formal framework. One possible objection to such conduct is that it is fundamentally "dishonest" in disguising official conduct. However, that objection is difficult to fit into the principles identified above.

Having set out the contours of Erewhon, I present my two main arguments in greater detail below.

\section{ERRONEOUS ASSUMPTIONS}

If one accepts that the Erewhonese government's conduct is not consistent with the rule of law, this suggests that the assumptions behind the major rule of law indices are inadequate to identify what is wrong in Erewhon. As noted above, the major indices place great emphasis on (a) law and order; (b) private property; (c) the role and independence of the 85 Id. at 16. 
courts and judiciary; (d) corruption; and (e) substantive rights. Yet the Erewhonese government could present a respectable argument that it performs well in each of these areas.

Taking law and order first, recall that Erewhon does not suffer from civil conflict. Nor does it have problems with violent or organised crime. Erewhonese law enforcement is highly respected - and, like other civil servants in the jurisdiction, incorruptible. However, this is not incompatible with the systematic exercise of prosecutorial discretion against political opponents in respect of "non-political" offences, or with bureaucratic harassment that falls short of criminal prosecution.

Nor would Erewhon's protection of private property necessarily raise eyebrows. Erewhon's constitution, and its primary legislation, are carefully modelled on those in respected commercial jurisdictions. Erewhonese officials could convincingly argue that their laws, and their courts, provide adequate protection for property. Yet bureaucrats would remain free systematically to exercise their administrative discretion in ways that disfavour political opponents, short of a regulatory taking for instance, by refusing to allow civil society NGOs to register as companies. 
What, then, of Erewhon's courts and its judges? It is perfectly possible for Erewhon's judges to act independently in the vast majority of cases - provided that they rule for the government or its proxies in the few cases that are politically significant - a problem I will return to further below. However, even if Erewhon's judges were not subject to such pressures in "sensitive" cases, that is not the end of the matter. As I noted earlier, bureaucratic harassment of political opponents puts them on the back foot by the time they arrive in a courtroom; in terms of time, money, and resources, it may scarcely matter what the outcome of the litigation will be.

Erewhon's leaders might then point to the absence of corruption in the jurisdiction, and with good reason. Yet the account presented in the rule of law tables, where corruption is largely equated with the straightforward taking of bribes, does not capture a situation where the bureaucracy is encouraged by regime incumbents (through mechanisms such as promotion through the ranks) to exercise its discretion in ways that systematically disfavour political opponents.

Lastly, we come to substantive rights. As noted above, Erewhon's leaders might conceivably take one of two approaches: to 
deny the importance of rights outright, or to argue that certain alleged infringements of rights are justified by countervailing factors. In addition, of the leading indices, only WJP and BTI assume that uneven protection of rights might occur on the basis of political affiliation. ${ }^{86}$

In contrast, the leading indices are largely silent on the threats that Erewhon does pose to the rule of law. Recall that the tools at Erewhon's disposal include (1) selective application of the law by administrative bodies; (2) capricious exercise of administrative discretion; (3) secret "administrative guidelines"; (4) making rules practically impossible to comply with; and (5) using private (or ostensibly private) actors to engage in repression. Measured against such acts, the major indices are all deeply deficient:

1. Only FW and WJP address the prospect of political influence over prosecutors. ${ }^{87}$ However, neither index considers the prospect of selective enforcement by administrative bodies outside the criminal justice system;

86 BTI 2018 Codebook for Country Assessments, supra note 59, at 21 (factor 3.4); Rule of Law Index 2019, supra note 22, at 12 (factor 4).

87 Methodology 2019, supra note 52; Rule of Law Index 2019, supra note 22, at 13 (factor 8.6). 
2. None of the indices consider the arbitrary exercise of lawfully conferred administrative discretion at any meaningful length (except WGI and Heritage, who only consider such discretion insofar as it relates to private property rights).$^{88}$ For instance, although WJP refers to "improper government or political influence" as a threat to civil and criminal justice, ${ }^{89}$ it does not refer to such influence as being a factor that undermines regulatory enforcement; ${ }^{90}$

3. Only WJP addresses the accessibility of administrative regulations (as a subset of factor 3.1); ${ }^{91}$ and

4. None of the indices address the possibility that rules might be made practically impossible to comply with - whether for the entire population, or for a subset thereof (with the possible exception of regulatory takings of property.

88 Rule of Law, supra note 40; Miller et al., supra note 47, at 453-54.

89 Id. (factors 7.4 and 8.6).

90 Id. (factor 6).

91 Rule of Law Index 2019, supra note 22, at 12. 
Some of the conduct described above might be addressed with reference to substantive rights. However, the existing indices' discussion of substantive rights is deficient for the reasons set out above.

It should now be clear that Erewhon's president could consolidate her political control in ways that rule of law indices do not currently treat as major threats. I now turn to my second argument: that such indices do not adequately consider outliers.

\section{OUTLIERS MATTER}

In arguing that indices do not adequately consider outliers, I am not making an argument based on the specific factors that rule of law indices include or exclude. Rather, this argument is a criticism of the general approach that these indices take to the exercise of "measuring" the rule of law.

The major indices are general indicators: they purport to "take the temperature" ${ }^{92}$ of a legal system at large, rather than address specific cases. ${ }^{93}$ The factors that the indices' compilers choose to emphasise reflect that approach: it should be obvious that a jurisdiction on the

92 See Botero \& Ponce, supra note 74, at 27.

93 See Botero et al., supra note 88, at 163. 
brink of a civil war will fare markedly worse than, say, a liberal electoral democracy.

However, the "taking the temperature" approach runs the risk of undervaluing specific cases. Suppose that 95 per cent of Erewhon's commercial cases are handled impeccably by independent judges, but the remaining five per cent - which involve "national champions" or "sensitive" subject matter - are not. How should that five per cent be treated?

One possibility is to simply give a clean bill of health to Erewhon, on the basis that 95 per cent of cases are satisfactorily handled. There are two problems with such an approach. First, it is unlikely to provide meaningful guidance to an investor who intends to compete with a national champion, or to provide comfort to an unhappy litigant who finds herself in the latter five per cent of cases. ${ }^{94}$ Second, such a weighting presupposes that all of the cases considered are of equal importance. ${ }^{95}$ On the contrary, worst-case scenarios may well have a

94 See Botero et al., supra note 82, at 163.

95 See Elizabeth Redden, Book publishers part ways with Springer Nature over concerns about censorship in China, Inside Higher Ed (Oct. 3, 2018), https://www.insidehighered.com/news/2018/10/03/book-publishers-part-waysspringer-nature-over-concerns-about-censorship-china (on an academic publisher's argument that under $1 \%$ of its articles were blocked in Mainland China). 
disproportionate impact due to (inter alia) their chilling effects elsewhere within the sector. ${ }^{96}$ ing.

One might downplay the effects of these problems and argue that, imperfect as they are, the existing rule of law measures are useful in conveying a general impression of the rule of law in a particular jurisdiction. There are two objections to this argument. First, such an argument assumes that governments will not have incentives to engage in further tactical behaviour (as opposed to genuine, good-faith efforts to improve). On the contrary, it is unlikely that a regime would choose the latter (which would likely involve the relinquishment of political control) over the former, in the absence of other factors - such as the risk of getting caught. Second, in cases such as Erewhon's, a defective index is arguably worse than no index at all, insofar as it provides a veneer of legitimacy to acts of abusive legalism. In such situations, defective measurements are therefore not merely not helping, but actively doing harm.

96 See, e.g., Brandice Canes-Wrone \& Michael Dorf, Measuring the Chilling Effect, N.Y.U. L. ReV. 1095, 1095-97 (2015) (addressing the U.S. Supreme Court's "chilling effect" jurisprudence). 
If one accepts that Erewhon highlights the deficiencies of existing rule of law indices, it falls to consider what ought to be done about such indices. The most radical solution would be to get rid of the whole notion of "measuring" the rule of law using indices. However, given the trend towards quantification in global governance, such an approach does not seem viable.

If the rule of law indices are here to stay, how should they be changed to reflect the challenges that Erewhon poses? I offer two tentative suggestions. First, indices should focus more on formal attributes of the rule of law. ${ }^{97}$ Indices that take seriously the 11 formal criteria set out above, rather than addressing piecemeal topics such as law and order or the absence of corruption, may be less vulnerable to being "gamed" in the ways I discuss above. They would also do better than existing criteria at capturing abusive exercises of administrative power that do not reach a courtroom.

97 It is striking that academic studies have largely advocated the adoption of thin conceptions. See, e.g., Janse et al., supra note 33, sec. 8 ("there is value in starting the conceptualisation from a thinner conception of the rule of law"); Skaaning, supra note 4, at 451; MØLler \& SKAANING, supra note 22, at 45-46; Versteeg \& Ginsburg, supra note 3, at 105-6. 
Second, compilers of indices should give greater consideration to how to address "outlier" cases. For instance, the indices' compilers might ask whether (and, if so, how) ordinary commercial disputes, or exercises of administrative discretion, would be treated differently based on the parties' political affiliation. Such an approach would be more effective at highlighting abusive legalism than the approach currently taken by most indices.

More significantly, however, compilers of indices should be prepared to state explicitly, and to reevaluate, their threat models. As long as there are jurisdictions like Erewhon that have significant incentives both to do well in rule of law indices and to increase political repression, there will be a motive to game such indices. Although stamping out such abuses altogether is an impossible task, a more forensic approach to identifying threats to the rule of law will at least make indices more robust. 